\title{
The Impact of an Epidemic: An Analysis of HIV and Early Marriage for Women in Sub-Saharan Africa
}

\author{
Kpoti Kitissou \\ State University of New York at Oneonta \\ Bong Joon Yoon \\ Binghamton University
}

This paper studies the relationship between HIV prevalence and marriage in Sub-Saharan Africa. We use repeated cross-sectional data from the Demographic and Health Surveys for Sub-Saharan Africa from 2003-2013 and find that the HIV epidemic is associated with higher likelihood of marriage. For young women, especially adolescent girls, the findings imply an important consequence of the HIV epidemic: its negative effect on educational attainment of girls through early marriage. Furthermore, the impact of the HIV epidemic on marriage, which varies from region to region, is shown to be weakest in Southern Africa, the region with the highest degree of HIV prevalence.

Keywords: early marriage, HIV, Sub-Saharan Africa

\section{INTRODUCTION}

Understanding factors that influence adolescent marriage is important, especially with the introduction of gender equality in education into the United Nations' new Sustainable Development Goals for 2030. The purpose of this paper is to analyze the effects of the HIV epidemic on the marriage of young women in SubSaharan Africa. HIV is a global epidemic that has primarily affected Sub-Saharan Africa and its effects on the economies of developing countries have been debated over three decades. It should be noted that in some ways there has been substantial progress since the mid-1990s. From 1997 to 2010, new infections worldwide fell by 21 percent, although through 20161.8 million new infections are annually recorded (UNAIDS, 2011, 2017). HIV related deaths also peaked in 2005 at 1.9 million (UNAIDS 2017). Despite these worldwide improvements, HIV remains a major concern in Sub-Saharan Africa. Sixty-eight percent of all people living with HIV reside in Sub-Saharan Africa. The lack of antiretroviral therapy there makes HIV prevention and behavioral change crucial in this part of the world. Only recently have marital coping strategies entered the discussion within this region (Clark, 2004; Reniers, 2008; Anglewicz \& Reniers, 2014; Greenwood et al., 2017).

Adolescent marriage, defined as formal marriage or informal union in which at least one of the parties is younger than 18 years of age, accounts for nearly 40 percent of all marriages in Sub-Saharan Africa (SDG, 2017). Aside from the psychological effects of early marriage and childbirth, early marriage is also associated with the end of schooling and a loss of personal bargaining power when a girl enters into a marriage (Clark, Bruce, \& Dude, 2006; Ueyama \& Yamauchi, 2009). Marriages in Sub-Saharan Africa are 
also most prevalent between the ages 15-17 for women (Table 4). Although many Sub-Saharan African countries have adopted laws prohibiting marriage prior to age 18, many adolescent girls enter into marriage because of cultural norms, household poverty, and the financial incentives of their parents or guardians (UNFPA, 2012; HRW, 2015).

Among past studies on the impacts of the HIV epidemic in Sub-Saharan Africa, Fortson (2011) documents that the HIV epidemic has an overall negative influence on the educational outcomes of both males and females. Forston also finds that women are less educated than men in HIV afflicted areas but does not provide an explanation as to why. Using data from the 2004 Malawi Demographic and Health Survey (DHS), Ueyama and Yamauchi (2009) associate the decline in the age when women marry with a reduction of schooling for these women, a diminishment of their ability to negotiate within marriage, and an overall reduction of the human capital attainment of their children in accordance to the quality-quantity trade-off of Becker and Lewis (1973). ${ }^{1}$

Beegle and Krutikova (2008) use data from the Kagera (Tanzania) Health and Development Survey to evidence that girls orphaned before age 15, likely because of the HIV epidemic, are more likely to marry between the ages of 17 to 23. Beegle and Krutikova (2009) also address the potentiality of marriage as a safety net from HIV contraction and the negative effect of early marriage on educational outcomes. On the other hand, Palermo and Peterman (2009) report inconclusive results for orphaned girls ages 15-17 and their transition into marriage. They explain that orphaned adolescent girls may not marry because of the stigmatization of suspicions that their parent(s) died due to an HIV contraction. They also suggest that adolescent girls may delay marriage because of the income shock from the death of a parent resulting in a greater demand for housework or income contribution to the family from the orphaned girl. Clark, Poulin, and Kohler (2009) and Grant and Soler-Hampejsek (2014) find that the HIV epidemic does not deter the aspiration to marry, because the perceived risk of a future HIV infection does not influence the overall desire to marry.

Despite inconsistencies among past studies regarding the impact of the HIV epidemic on marriage in Sub-Saharan Africa, we believe that the HIV epidemic encourages marriage of young girls, which hurts their educational outcomes. To confirm this relationship, we attempt an extensive empirical investigation using the pooled cross-sectional data of 32 Sub-Saharan African countries from the DHS. In all, we have utilized 55 rounds of surveys from 2003-2013. Our results show that the HIV epidemic in Sub-Saharan Africa is positively associated with the marriage of women during their prime age as well as adolescence. For adolescent boys, we find a negligible influence of the HIV epidemic on their likelihood of marriage. The remainder of the paper is organized by a section that describes our data, a discussion section of our empirical model and results, and a conclusion section.

\section{THE DATA}

The DHS is a nationally representative sample with respect to socioeconomics, health, and reproduction outcomes. From the DHS we gather information on each respondent's age, age at first marriage if married previously, education, and location of residence (urban or rural). HIV prevalence data are country-bycountry data for adults aged 15-49 from 1990-2013 and drawn from UNAIDS (http://aidsinfo.unaids.org) in order to match the corresponding HIV prevalence to the year respondents made their marriage decision. The UNAIDS estimates the HIV prevalence of a country by using a combination of antenatal clinics and nationally representative population-based surveys, HIV case reporting, and AIDS-related mortality data (UNAIDS, 2014).

Table 1 presents the definitions of the variables used in our study. Table 2 provides a list of the countries included in our analysis. The duration until the respondent's first marriage dependent variable is measured as the age at their first marriage. The binary dependent variable is whether the respondent ever married. Among explanatory variables, country HIV prevalence is the HIV prevalence rate of the respondent's country of residence in the year of their first marriage or, for the unmarried, in the survey year. Age cohorts range from ages 15-17, 18-20, 21-25, and 26-30, with the reference cohort being ages 31-64. 
TABLE 1

VARIABLE DEFINITIONS

\begin{tabular}{|c|c|c|c|c|c|c|}
\hline Sample A & \multirow{2}{*}{\multicolumn{6}{|c|}{$\begin{array}{l}\text { Samples only the individuals (in the DHS) who were unmarried in the } \\
\text { beginning of the survey } \\
\text { Samples all the individuals except those who married before age } 15\end{array}$}} \\
\hline Sample B & & & & & & \\
\hline \multicolumn{7}{|l|}{ Dependent Variable } \\
\hline $\begin{array}{c}\text { Sample A - Married in the } \\
\text { Survey Year }\end{array}$ & \multicolumn{6}{|c|}{$=1$ if married during the survey year; $=0$ otherwise } \\
\hline Sample B - Ever married & \multicolumn{6}{|c|}{$=1$ if ever married; $=0$ otherwise } \\
\hline \multicolumn{7}{|l|}{ Right Hand Side Variables: } \\
\hline Country HIV Prevalence & \multicolumn{6}{|c|}{$\begin{array}{l}\text { Respondent's country HIV prevalence rate at the age of first marriage if } \\
\text { married and the rate in the survey year if not married }\end{array}$} \\
\hline$E d u$ & \multirow{2}{*}{\multicolumn{6}{|c|}{$\begin{array}{l}\text { Respondent's number of years of schooling in the survey year } \\
=1 \text { if respondent resides in an urban setting in the survey year; =0 } \\
\text { otherwise }\end{array}$}} \\
\hline Urban & & & & & & \\
\hline \multicolumn{7}{|l|}{ Sample A } \\
\hline Age 15 to 17 & \multicolumn{6}{|c|}{$=1$ if respondent is age 15 to 17 in the survey year; $=0$ otherwise } \\
\hline Age 18 to 20 & \multicolumn{6}{|c|}{$=1$ if respondent is age 18 to 20 in the survey year; $=0$ otherwise } \\
\hline Age 21 to 25 & \multicolumn{6}{|c|}{$=1$ if respondent is age 21 to 25 in the survey year; $=0$ otherwise } \\
\hline Age 26 to 30 & \multicolumn{6}{|c|}{$=1$ if respondent is age 26 to 30 in the survey year; $=0$ otherwise } \\
\hline \multicolumn{7}{|l|}{ Sample B } \\
\hline Age 15 to 17 & \multicolumn{6}{|c|}{$\begin{array}{l}=1 \text { if unmarried respondent is age } 15 \text { to } 17 \text { in the survey year or married } \\
\text { respondent married between age } 15 \text { to } 17 ;=0 \text { otherwise }\end{array}$} \\
\hline Age 18 to 20 & \multicolumn{6}{|c|}{$\begin{array}{l}=1 \text { if unmarried respondent is age } 18 \text { to } 20 \text { in the survey year or married } \\
\text { respondent married between age } 18 \text { to } 20 ;=0 \text { otherwise }\end{array}$} \\
\hline Age 21 to 25 & \multicolumn{6}{|c|}{$\begin{array}{l}=1 \text { if unmarried respondent is age } 21 \text { to } 25 \text { in the survey year or married } \\
\text { respondent married between age } 21 \text { to } 25 ;=0 \text { otherwise }\end{array}$} \\
\hline Age 26 to 30 & \multicolumn{6}{|c|}{$\begin{array}{l}=1 \text { if unmarried respondent is age } 26 \text { to } 30 \text { in the survey year or married } \\
\text { respondent married between age } 26 \text { to } 30 ;=0 \text { otherwise }\end{array}$} \\
\hline \multicolumn{7}{|c|}{$\begin{array}{l}\text { DHS only interviews those aged } 15 \text { or older. However, it provides information on the age at first marriage for th } \\
\text { respondents who have ever married which can be before age } 15 \text {. }\end{array}$} \\
\hline \multicolumn{7}{|c|}{$\begin{array}{c}\text { TABLE } 2 \\
\text { COUNTRY SAMPLE DISTRIBUTION }\end{array}$} \\
\hline \multirow[b]{2}{*}{ Country } & \multicolumn{2}{|c|}{ Full Sample } & \multicolumn{2}{|c|}{ Female Sample } & \multicolumn{2}{|c|}{ Male Sample } \\
\hline & Percent & $\mathrm{N}$ & Percent & $\mathrm{N}$ & Percent & $\mathrm{N}$ \\
\hline Benin & 2.46 & 23,115 & 2.77 & 17,794 & 1.8 & 5,321 \\
\hline Burkina Faso & 1.71 & 16,082 & 1.94 & 12,477 & 1.22 & 3,605 \\
\hline Burkina Faso & 2.6 & 24,394 & 2.66 & 17,087 & 2.47 & 7,307 \\
\hline Burundi & 1.46 & 13,669 & 1.46 & 9,389 & 1.45 & 4,280 \\
\hline Cameroon & 1.7 & 15,936 & 1.66 & 10,656 & 1.79 & 5,280 \\
\hline Cameroon & 2.41 & 22,617 & 2.4 & 15,426 & 2.43 & 7,191 \\
\hline Chad & 0.85 & 7,972 & 0.95 & 6,085 & 0.64 & 1,887 \\
\hline
\end{tabular}




\begin{tabular}{|c|c|c|c|c|c|c|c|}
\hline Congo, Republic & 2005 & 1.09 & 10,197 & 1.1 & 7,051 & 1.06 & 3,146 \\
\hline Congo, Republic & 2011 & 1.7 & 15,964 & 1.68 & 10,819 & 1.74 & 5,145 \\
\hline Congo Democrat & 2007 & & & & & & \\
\hline Republic & $2013-$ & 1.57 & 14,752 & 1.55 & 9,995 & 1.61 & 4,757 \\
\hline Congo DR & 2014 & 2.93 & 27,483 & 2.93 & 18,827 & 2.93 & 8,656 \\
\hline Ethiopia & 2005 & 2.14 & 20,103 & 2.19 & 14,070 & 2.04 & 6,033 \\
\hline Ethiopia & 2011 & 3.26 & 30,625 & 2.57 & 16,515 & 4.77 & 14,110 \\
\hline Gambia & 2013 & 1.5 & 14,054 & 1.59 & 10,233 & 1.29 & 3,821 \\
\hline Ghana & 2003 & 1.14 & 10,706 & 0.89 & 5,691 & 1.7 & 5,015 \\
\hline Ghana & 2008 & 1.01 & 9,484 & 0.76 & 4,916 & 1.55 & 4,568 \\
\hline Guinea & 2005 & 1.19 & 11,128 & 1.24 & 7,954 & 1.07 & 3,174 \\
\hline Guinea & $\begin{array}{l}2012 \\
2011-\end{array}$ & 1.38 & 12,924 & 1.42 & 9,142 & 1.28 & 3,782 \\
\hline Ivory Coast & 2012 & 1.62 & 15,195 & 1.56 & 10,060 & 1.74 & 5,135 \\
\hline Kenya & $\begin{array}{l}2003 \\
2008-\end{array}$ & 1.25 & 11,773 & 1.27 & 8,195 & 1.21 & 3,578 \\
\hline Kenya & 2009 & 1.27 & 11,909 & 1.31 & 8,444 & 1.17 & 3,465 \\
\hline Lesotho & 2004 & 1.05 & 9,892 & 1.1 & 7,095 & 0.95 & 2,797 \\
\hline Lesotho & 2009 & 1.17 & 10,941 & 1.19 & 7,624 & 1.12 & 3,317 \\
\hline Liberia & 2007 & 1.4 & 13,101 & 1.1 & 7,092 & 2.03 & 6,009 \\
\hline Liberia & $\begin{array}{l}2013 \\
2008-\end{array}$ & 1.42 & 13,357 & 1.44 & 9,239 & 1.39 & 4,118 \\
\hline Madagascar & 2009 & 2.77 & 25,961 & 2.7 & 17,375 & 2.9 & 8,586 \\
\hline Malawi & 2004 & 1.59 & 14,959 & 1.82 & 11,698 & 1.1 & 3,261 \\
\hline Malawi & 2010 & 3.22 & 30,195 & 3.58 & 23,020 & 2.43 & 7,175 \\
\hline Mali & 2006 & 2 & 18,790 & 2.27 & 14,583 & 1.42 & 4,207 \\
\hline Mali & 2012 & 1.58 & 14,823 & 1.62 & 10,424 & 1.49 & 4,399 \\
\hline Mozambique & 2003 & 1.63 & 15,318 & 1.93 & 12,418 & 0.98 & 2,900 \\
\hline Mozambique & $\begin{array}{l}2011 \\
2006-\end{array}$ & 1.89 & 17,780 & 2.14 & 13,745 & 1.37 & 4,035 \\
\hline Namibia & 2007 & 1.46 & 13,719 & 1.52 & 9,804 & 1.32 & 3,915 \\
\hline Namibia & 2013 & 1.54 & 14,499 & 1.56 & 10,018 & 1.52 & 4,481 \\
\hline Niger & 2006 & 1.36 & 12,772 & 1.43 & 9,223 & 1.2 & 3,549 \\
\hline Niger & 2012 & 1.61 & 15,088 & 1.74 & 11,160 & 1.33 & 3,928 \\
\hline Nigeria & 2003 & 1.06 & 9,966 & 1.19 & 7,620 & 0.79 & 2,346 \\
\hline Nigeria & 2008 & 5.21 & 48,871 & 5.19 & 33,385 & 5.24 & 15,486 \\
\hline Nigeria & 2013 & 6 & 56,307 & 6.06 & 38,948 & 5.87 & 17,359 \\
\hline Rwanda & $\begin{array}{l}2005 \\
2007-\end{array}$ & 1.72 & 16,141 & 1.76 & 11,321 & 1.63 & 4,820 \\
\hline Rwanda & 2008 & 1.51 & 14,150 & 1.14 & 7,313 & 2.31 & 6,837 \\
\hline Rwanda & 2010 & 2.13 & 20,000 & 2.13 & 13,671 & 2.14 & 6,329 \\
\hline São Tomé and Príncipe & 2009 & 0.52 & 4,911 & 0.41 & 2,615 & 0.78 & 2,296 \\
\hline Senegal & $\begin{array}{l}2005 \\
2010-\end{array}$ & 1.96 & 18,363 & 2.27 & 14,602 & 1.27 & 3,761 \\
\hline Senegal & 2011 & 2.2 & 20,617 & 2.44 & 15,688 & 1.67 & 4,929 \\
\hline Sierra Leone & 2008 & 1.14 & 10,654 & 1.15 & 7,374 & 1.11 & 3,280 \\
\hline Swaziland (Eswatini) & $\begin{array}{l}2006 \\
2004-\end{array}$ & 0.97 & 9,143 & 0.78 & 4,987 & 1.41 & 4,156 \\
\hline Tanzania & 2005 & 1.38 & 12,964 & 1.61 & 10,329 & 0.89 & 2,635 \\
\hline Tanzania & 2010 & 1.35 & 12,666 & 1.58 & 10,139 & 0.85 & 2,527 \\
\hline
\end{tabular}

180 Journal of Applied Business and Economics Vol. 24(1) 2022 


\begin{tabular}{lllllrrr}
\hline Togo & 2013 & 1.49 & 13,956 & 1.47 & 9,480 & 1.51 & 4,476 \\
Uganda & 2006 & 1.18 & 11,034 & 1.33 & 8,531 & 0.85 & 2,503 \\
Zambia & 2007 & 1.45 & 13,646 & 1.11 & 7,146 & 2.2 & 6,500 \\
Zambia & 2013 & 3.32 & 31,184 & 2.55 & 16,411 & 5 & 14,773 \\
Zimbabwe & 2005 & 1.71 & 16,082 & 1.39 & 8,907 & 2.43 & 7,175 \\
& $2010-$ & & & & & & \\
Zimbabwe & 2011 & 1.77 & 16,651 & 1.43 & 9,171 & 2.53 & 7,480 \\
Total & & & 938,583 & & 642,982 & & 295,601 \\
\hline
\end{tabular}

Table 3 shows the summary statistics of our sample by gender. The average age at first marriage is 18 for females and 24 for males. Females have on average 1.6 fewer years of education than males.

Table 4 reports the distribution of age at first marriage and the average husband-wife age difference at wife's age at marriage. The most frequent age cohort at first marriage for females is ages 15-17, with 35.6 percent of all marriages occurring during that range. Males tend to marry later with most of their marriages occurring between ages 21-25. The average age gap between married females and their husbands ranges from 6 to 10 years.

TABLE 3

SUMMARY STATISTICS FOR THE WHOLE SAMPLE

\begin{tabular}{|c|c|c|c|c|c|c|c|c|c|}
\hline & \multicolumn{3}{|c|}{ Full Sample } & \multicolumn{3}{|c|}{ Female Sample } & \multicolumn{3}{|c|}{ Male Sample } \\
\hline & Mean & $\mathrm{SD}$ & $\mathrm{N}$ & Mean & SD & $\mathrm{N}$ & Mean & SD & $\mathrm{N}$ \\
\hline Ever Married & 0.7 & 0.5 & 938,566 & 0.7 & 0.4 & 642,977 & 0.6 & 0.6 & 295,589 \\
\hline Age at First Marriage & 19.5 & 5.2 & 642,869 & 17.9 & 4.2 & 474,725 & 23.8 & 23.8 & 168,144 \\
\hline Country HIV Prev. & 5.7 & 6.2 & 752,446 & 5.6 & 6.0 & 506,200 & 6.1 & 6.1 & 246,246 \\
\hline$E d u$ & 5.1 & 4.6 & 937,807 & 4.6 & 4.5 & 642,559 & 6.2 & 6.2 & 295,248 \\
\hline Urban & 0.4 & 0.5 & 938,583 & 0.4 & 0.5 & 642,982 & 0.4 & 0.4 & 295,601 \\
\hline Age & 29.1 & 10.3 & 938,583 & 28.4 & 9.5 & 642,982 & 30.6 & 30.6 & 295,601 \\
\hline
\end{tabular}

TABLE 4

AGE AT FIRST MARRIAGE AMONG THOSE EVER MARRIED AND AVERAGE HUSBANDWIFE AGE DIFFERENCE AT WIFE'S AGE AT MARRIAGE FOR THE WHOLE SAMPLE

\begin{tabular}{lccc}
\hline & Full Sample & Female Sample & Male Sample \\
\hline Age at First Marriage & & & \\
$<9$ & $0.05 \%$ & $0.10 \%$ & $0.01 \%$ \\
$10-14$ & 13.0 & 17.3 & 0.7 \\
$15-17$ & 28.4 & 35.7 & 7.6 \\
$18-20$ & 24.5 & 26.0 & 39.4 \\
$21-25$ & 21.7 & 15.5 & 21.2 \\
$26-30$ & 8.6 & 4.1 & 10.7 \\
$31-64$ & 3.8 & 1.3 & \\
& & Average husband-wife & \\
Wife's age at marriage & & age difference & \\
$15-17$ & & 9.9 & \\
$18-20$ & & 8.4 & \\
$21-25$ & & 7.5 & \\
$26-30$ & & 6.8 & \\
$31-64$ & & 6.2 & \\
\hline
\end{tabular}


In Table 5 we explore the relationships between educational outcomes and marital status across age cohorts. Among those ages 15-17, unmarried girls and boys have identical average years of education at 5.8 years. For older unmarried women cohorts, females on average have more years of education than unmarried males. Among married and unmarried girls aged 15-17, however, a larger difference exists in their educational attainment: On average, married adolescent girls attain only 2.7 years of education, which is around 3 years less than the unmarried ones. In Table 5 we also find that the gap in schooling between married and unmarried females rises among older cohorts. The differences in education attainment for married adolescent girls and boys is 2.5 years in favor of adolescent boys.

In Table 6 we observe married girls ages 15-17 have a 2.2 percent HIV infection rate compared to 1.6 percent for unmarried girls of the same age cohort. The trend reverses for females age 21 and older. Unmarried females aged 21-25 have an 8.1 percent HIV infection rate compared to 6.6 percent for married girls, and unmarried females ages 26-30 have a 14.6 percent HIV infection rate compared to an 8.7 percent HIV infection rate for their married counterparts. For males, there is relatively little difference in HIV infection rates for those who have married or never married.

TABLE 5

COMPARATIVE STATISTICS: SAMPLE MEANS OF EDUCATION ACROSS MARITAL STATUS, SEX, AND AGE COHORTS IN THE SURVEY YEAR FOR THE WHOLE SAMPLE

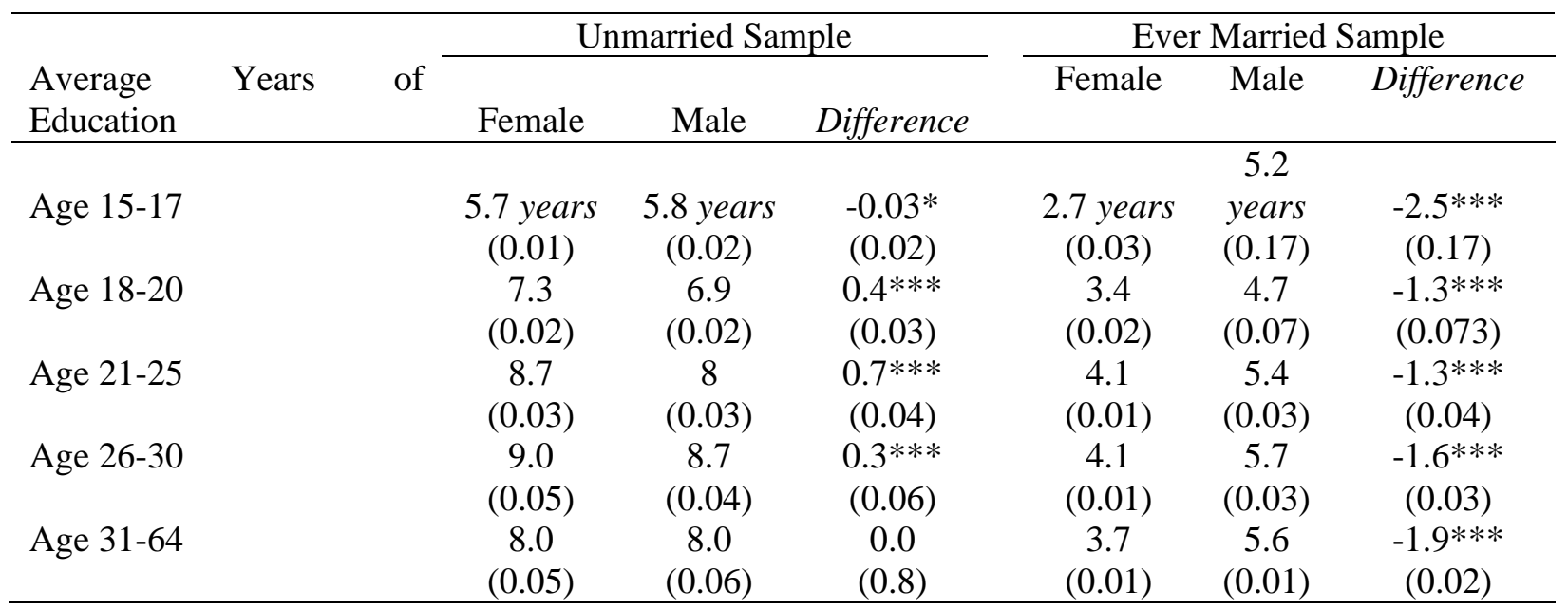

Standard errors are in parentheses. *,**, and $* * *$ denote significance levels at $10 \%, 5 \%$ and $1 \%$, respectively. 
TABLE 6

COMPARATIVE STATISTICS: HIV INFECTION RATES ACROSS MARITAL STATUS, SEX, AND AGE COHORTS IN THE SURVEY YEAR FOR THE WHOLE SAMPLE

\begin{tabular}{lccccccc}
\hline & \multicolumn{3}{c}{ Female Sample } & & \multicolumn{3}{c}{ Male Sample } \\
\cline { 2 - 4 } \cline { 7 - 8 } Has HIV (\%) & Unmarried & Ever Married & Difference & & Unmarried & Ever Married & Difference \\
\hline Age 15-17 & $1.6 \%$ & $2.2 \%$ & $-0.6^{* * *}$ & & $1.1 \%$ & & \\
Age 18-20 & $(0.1)$ & $(0.2)$ & $(0.2)$ & & $(0.07)$ & & \\
& 3.4 & 3.8 & $-0.4^{*}$ & & 1.32 & 1.51 & -0.18 \\
Age 21-25 & $(0.1)$ & $(0.2)$ & $(0.2)$ & & $(0.08)$ & $(0.31)$ & $(0.30)$ \\
& 8.1 & 6.6 & $1.5^{* * *}$ & & 2.50 & 3.56 & $-1.06^{* * *}$ \\
Age 26-30 & $(0.3)$ & $(0.1)$ & $(0.3)$ & & $(0.12)$ & $(0.19)$ & $(0.22)$ \\
& 14.6 & 8.7 & $5.9^{* * *}$ & & 5.27 & 5.75 & -0.48 \\
Age 31-64 & $(0.6)$ & $(0.2)$ & $(0.5)$ & & $(0.28)$ & $(0.17)$ & $(0.34)$ \\
& 21.5 & 9.7 & $11.8^{* * *}$ & & 8.8 & 7.6 & $1.2^{* *}$ \\
& $(0.9)$ & $(0.1)$ & $(0.6)$ & & $(0.5)$ & $(0.1)$ & $(0.5)$ \\
\hline
\end{tabular}

DHS provides HIV test for respondents who wish to participate. Not all surveys have an HIV test component. The summary statistic from Table 6 is gathered from HIV test results from 35 out of the 55 surveys. The surveys are: Burkina Faso (2003, 2010), Burundi (2010), Congo - Democratic Republic (2003, 2013-14), Cameroon (2004, 2011), Ethiopia (2005, 2011), Ghana (2003), Guinea (2005, 2012), Ivory Cost (2011-2012), Kenya (2003, 2008-09), Liberia (2007, 2013), Lesotho (2004, 2009), Mali (2006, 2012), Malawi (2004, 2010), Niger (2006, 2012), Rwanda (2007-08, 2010), Sierra Leone (2008), Senegal (2010-11), Sao Tome and Principle (2009), Swaziland/Eswatini (2006), Zambia (2007, 2013), and Zimbabwe (2005, 2010-11).

\section{EMPIRICAL MODEL AND RESULTS}

To examine the relationship between the HIV prevalence rate and first marriage in Sub-Saharan Africa, we first consider a narrow sample of the individuals who were not married at the beginning of the survey period (sample A) to study their decisions to marry or stay single during the identical period, the survey year. Defining a binary dependent variable $Y_{i}$ to equal 1 if an individual marries during the survey year and 0 otherwise, the decision to marry can be specified by the following probit model: ${ }^{2}$

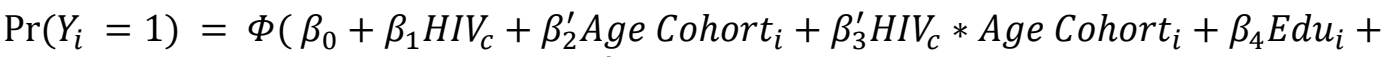

$$
\begin{aligned}
& \left.\beta_{5} \operatorname{Urban}_{i}+\beta_{6}^{\prime} R_{i}\right)
\end{aligned}
$$

where $\Phi$ denotes the cumulative standard normal distribution. $H I V_{c}, E d u_{i}, \operatorname{Urban}_{i}$ and $R_{i}$ are measured at survey time. $H I V_{c}$ is the HIV prevalence rate faced by the individual in country $c . E d u_{i}$ is the individual's years of education. $U r b a n_{i}$ indicates whether the individual resides in an urban area and $R_{i}$ captures the country fixed effects. Age Cohort ${ }_{i}$ is a vector of the individual's age cohort dummies at survey time, which are the following age categories: 15-17, 18-20, 21-25, and 26-30. The youngest age cohort in sample $\mathrm{A}$ is 15-17, because the DHS requires the minimum age at the survey time to be 15 . The cross-product term $H_{I}$ * Age Cohort ${ }_{i}$ is included to capture the differential marriage effects of the HIV prevalence rate across age cohorts.

Education, an explanatory variable, can be influenced by marriage decisions, causing an endogeneity bias in estimation. ${ }^{3}$ Therefore, we also estimated the model without Edu. Columns (1) and (3) of Table 7 list estimated results for the probit specification without $E d u$ using sample A. All the estimated effects are statistically significant. Urban residence has a negative effect on marriage, reducing marriage probability by 3.75 percentage points for females and by 1.45 percentage points for males. The effects of the age cohort dummies show that the reference group, unmarried at Age 31-64 has the lowest probability to marry. Among females, Age 15-17 have a 4.21 percentage point advantage in marriage probability over the reference group. The advantage in marriage probability over the reference group increases with older age 
group, reaching a peak at Age 26-30 (7.81\%). The same pattern is found among males: Age 31-64 have the lowest marriage prospect, followed by Age 15-17 (0.14\% advantage) with every successively older group having a higher advantage, peaking at Age 26-30 (2.46\% advantage).

\section{TABLE 7 \\ ESTIMATED PROBIT MODEL MARGINAL EFFECTS WITHOUT EDUCATION AS AN EXPLANATORY VARIABLE}

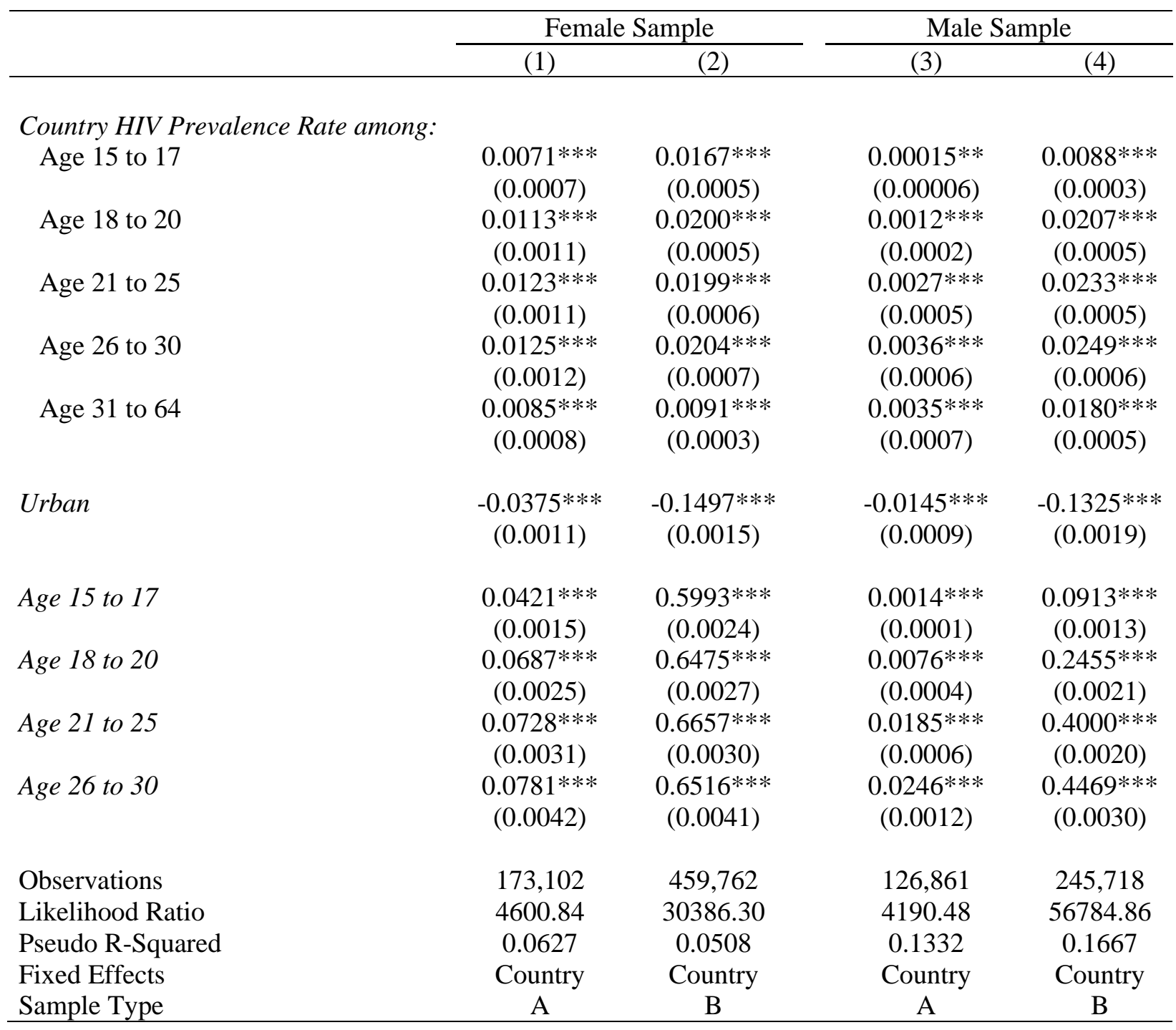

The estimated marginal effect of the HIV prevalence rate on marriage also differs across age cohorts. Among females (column (1)), one percentage point rise in the HIV rate increases marriage probability by 0.71 percentage points for Age 15-17, which is followed by successively higher effects for older age groups. The effect peaks at 1.25 percentage points for Age 26-30 and then declines to 0.85 percentage points for Age 31-64 (the reference group). Among males (column (3)), the marriage effect of the HIV rate shows the same pattern across age cohorts but is much smaller than among females. It is almost negligible for Age 15-17 (0.0155\%), increases with each older cohort, peaking at $0.36 \%$ for Age 26-30, and declines slightly to $0.35 \%$ for Age $31-64$.

The comparison by gender and age cohort shows that the marginal effects of the HIV rate on marriage are high among women ages 18-30. It is also observed that the effect among adolescent girls (Age 15-17) 
is considerably higher at more than half the peak rate observed for Age 26-30. Noting that marriage is associated with severely reduced schooling for African women Age 15-17 (Table 5), a higher HIV prevalence leads to diminished educational achievement for adolescent women because of their early marriage.

A shortcoming of the narrow sample $\mathrm{A}$ is that it excludes the individuals who married before the survey year. We can use the whole sample information (Sample B), which includes these individuals, by redefining $Y$ to include those who have ever married. ${ }^{4}$ A convenient way to define $Y$ in the whole sample is simply defining $Y_{i}=1$ if the respondent has ever married, and $Y_{i}=0$ otherwise. ${ }^{5}$ For those who married before survey time, $\mathrm{HIV}_{c}$ and $\mathrm{Age} \mathrm{Cohort}_{c}$ are measured at the time of marriage, while Edu $u_{i}, \operatorname{Urban}_{i}$ and $R_{i}$ are those measured at survey time. $H I V_{c}$ for the married at their various years of marriage is obtained from UNAIDS data. $E d u_{i}, \operatorname{Urban}_{i}$ and $R_{i}$ are the same as in sample A, those reported at survey time, since the values of these variables are unavailable outside of the survey time.

Although sample B includes more observations, it introduces additional unobserved error into the model. Sample A considers marriage decisions made during the survey year which is the same calendar year for everyone and avoids year-to-year marriage market variations. Sample B includes those who married in years prior to the survey year when the marriage market conditions diverged. That is, sample A has the benefit of less uncertainty but suffers from less information, while sample B enjoys more information despite greater uncertainty. Hence, we also consider the whole sample which includes the individuals married before survey time (sample B).

The estimated results using sample B are given in columns (2) and (4) of Table 7 for the probit specification without using $E d u$. They show similar patterns as with sample A. The estimated coefficients are larger in absolute value, while they are all are statistically significant. First, among the females (column (2)), Urban residence decreases marriage probability by 14.97 percentage points for females and by 13.25 percentage points for males. The coefficients for the age cohort dummies are lowest among the unmarried Age 31-64. The advantage in marriage probability over the reference group is 59.93 percentage points for Age 15-17 and 65.00-67.00 percentage points for Age 18-20, 21-25, and 26-30, respectively. Among males (column (4)), again, the marriage prospect (during the next year period) given that they are unmarried currently, is lowest for Age 31-64 (reference group). The percentage points advantage over the reference group is 9.13 for Age 15-17, increasing with age and peaking at 44.69 for Age 26-30.

The estimated marginal effect of the HIV prevalence rate on marriage across age cohorts using sample B show a similar pattern as with sample A. Among females, one percentage point rise in the HIV rate increases marriage probability by 1.67 percentage points for Age 15-17, followed by a higher effect for each next age group, peaking at 20.40 for Age 26-30 before dropping to 0.91 for Age 31-64 (the reference group). Among males, the marriage effect of the HIV rate is lowest for Age 15-17 (0.88 percentage points), increases with each older cohort, peaking at 2.49 for Age 26-30, and declines slightly to 1.80 for Age 3164.

As with sample A, the marginal effects of the HIV rate on marriage are high among women of ages 1830 in sample B. The effect among adolescent girls (Age 15-17) is almost as high as the peak rate for Age 26-30, again implying diminished educational opportunities for adolescent women due to early marriage. The probit model specification with $E d u$ was also estimated as shown in Table 8, which provides essentially the same findings as the model without $E d u$. 
TABLE 8

ESTIMATED PROBIT MODEL MARGINAL EFFECTS WITH EDUCATION AS AN EXPLANATORY VARIABLE

\begin{tabular}{|c|c|c|c|c|c|}
\hline & & \multicolumn{2}{|c|}{ Female Sample } & \multicolumn{2}{|c|}{ Male Sample } \\
\hline & & (1) & (2) & 4) & $(5)$ \\
\hline $\begin{array}{l}\text { Country HIV Prevalence } \\
\text { mong: }\end{array}$ & Rate & & & & \\
\hline Age 15 to 17 & & $\begin{array}{c}0.0054 * * * \\
(0.0007)\end{array}$ & $\begin{array}{c}0.0182 * * * \\
(0.0005)\end{array}$ & $\begin{array}{l}0.00010 * \\
(0.00006)\end{array}$ & $\begin{array}{c}0.0086^{* * * *} \\
(0.0003)\end{array}$ \\
\hline Age 18 to 20 & & $\begin{array}{c}0.0095 * * * \\
(0.0010)\end{array}$ & $\begin{array}{c}0.0217 * * * \\
(0.0005)\end{array}$ & $\begin{array}{l}0.0010 * * * \\
(0.0002)\end{array}$ & $\begin{array}{c}0.0209 * * * \\
(0.0005)\end{array}$ \\
\hline Age 21 to 25 & & $\begin{array}{l}0.0111 * * * \\
(0.0012)\end{array}$ & $\begin{array}{l}0.0207 * * * \\
(0.0005)\end{array}$ & $\begin{array}{l}0.0024 * * * \\
(0.0005)\end{array}$ & $\begin{array}{c}0.0236^{* * * *} \\
(0.0005)\end{array}$ \\
\hline Age 26 to 30 & & $\begin{array}{c}0.0111 * * * \\
(0.0014)\end{array}$ & $\begin{array}{c}0.0196 * * * \\
(0.0007)\end{array}$ & $\begin{array}{c}0.0033 * * * \\
(0.0007)\end{array}$ & $\begin{array}{c}0.0256^{* * * *} \\
(0.0006)\end{array}$ \\
\hline Age 31 to 64 & & $\begin{array}{c}0.0065 * * * \\
(0.0008)\end{array}$ & $\begin{array}{l}0.0093 * * * \\
(0.0003)\end{array}$ & $\begin{array}{l}0.0030 * * * \\
(0.0007)\end{array}$ & $\begin{array}{c}0.0179 * * * \\
(0.0005)\end{array}$ \\
\hline Urban & & $\begin{array}{c}-0.0183 * * * \\
(0.0012)\end{array}$ & $\begin{array}{c}-0.0537 * * * \\
(0.0015)\end{array}$ & $\begin{array}{c}-0.0082 * * * \\
(0.0010)\end{array}$ & $\begin{array}{c}-0.0786^{* * * *} \\
(0.0020)\end{array}$ \\
\hline Education & & $\begin{array}{c}-0.0072 * * * \\
(0.0002)\end{array}$ & $\begin{array}{l}-0.0305 * * * \\
(0.0002)\end{array}$ & $\begin{array}{l}-0.0020 * * * \\
(0.0001)\end{array}$ & $\begin{array}{c}-0.0164 * * * \\
(0.0002)\end{array}$ \\
\hline Age 15 to 17 & & $\begin{array}{c}0.0394 * * * \\
(0.0014)\end{array}$ & $\begin{array}{c}0.5748 * * * \\
(0.0023)\end{array}$ & $\begin{array}{c}0.0013 * * * \\
(0.0001)\end{array}$ & $\begin{array}{c}0.0880 * * * \\
(0.0013)\end{array}$ \\
\hline Age 18 to 20 & & $\begin{array}{c}0.0699 * * * \\
(0.0025)\end{array}$ & $\begin{array}{c}0.6380 * * * \\
(0.0026)\end{array}$ & $\begin{array}{l}0.0075 * * * \\
(0.0004)\end{array}$ & $\begin{array}{c}0.2416^{* * * *} \\
(0.0020)\end{array}$ \\
\hline Age 21 to 25 & & $\begin{array}{c}0.0822 * * * \\
(0.0034)\end{array}$ & $\begin{array}{l}0.6814 * * * \\
(0.0029)\end{array}$ & $\begin{array}{l}0.0186 * * * \\
(0.0006)\end{array}$ & $\begin{array}{c}0.3987 * * * \\
(0.0020)\end{array}$ \\
\hline Age 26 to 30 & & $\begin{array}{c}0.0891 * * * \\
(0.0046)\end{array}$ & $\begin{array}{c}0.6849 * * * \\
(0.0038)\end{array}$ & $\begin{array}{c}0.0253 * * * \\
(0.0012)\end{array}$ & $\begin{array}{c}0.4508 * * * \\
(0.0030)\end{array}$ \\
\hline Observations & & 172,963 & 459,457 & 126,675 & 245,418 \\
\hline Likelihood Ratio & & 6885.62 & 58254.46 & 4499.98 & 61968.85 \\
\hline Pseudo R-Squared & & 0.0939 & 0.0974 & 0.1432 & 0.1821 \\
\hline Fixed Effects & & Country & Country & Country & Country \\
\hline Sample Type & & A & $\mathrm{B}$ & A & $\mathrm{B}$ \\
\hline
\end{tabular}


TABLE 9

COUNTRY HIV PREVALENCE RATE SUMMARY STATISTIC BY AFRICAN REGION

\begin{tabular}{|c|c|c|c|c|}
\hline & $\begin{array}{c}(1) \\
\text { Central } \\
\text { Africa } \\
\end{array}$ & $\begin{array}{c}(2) \\
\text { Eastern } \\
\text { Africa }\end{array}$ & $\begin{array}{c}(3) \\
\text { Southern } \\
\text { Africa }\end{array}$ & $\begin{array}{c}(4) \\
\text { Western } \\
\text { Africa } \\
\end{array}$ \\
\hline \multicolumn{5}{|l|}{ Sample A } \\
\hline Avg. Country HIV Prevalence Rate (\%) & $\begin{array}{c}2.8 \\
(1.6)\end{array}$ & $\begin{array}{c}4.0 \\
(1.8)\end{array}$ & $\begin{array}{l}15.8 \\
(4.4)\end{array}$ & $\begin{array}{c}2.0 \\
(1.1)\end{array}$ \\
\hline Range & $1.1-5.3$ & $0.6-7.5$ & $10.3-26.3$ & $0.5-3.7$ \\
\hline Observations & 41,800 & 63,256 & 77,386 & 117,521 \\
\hline \multicolumn{5}{|l|}{ Sample B } \\
\hline Avg. Country HIV Prev & $\begin{array}{c}2.9 \\
(1.7)\end{array}$ & $\begin{array}{c}4.4 \\
(2.6)\end{array}$ & $\begin{array}{l}15.3 \\
(5.5)\end{array}$ & $\begin{array}{c}2.0 \\
(1.3)\end{array}$ \\
\hline Rang & $1.1-5.8$ & $0.2-12.6$ & $0.7-28.7$ & $0.1-6.9$ \\
\hline Observations & 109,227 & 142,297 & 177,761 & 323,161 \\
\hline \multicolumn{5}{|c|}{$\begin{array}{l}\text { Standard deviation in parentheses. We use the African Union's regional grouping of countries as follows. Central } \\
\text { (Middle) Africa: Burundi, Cameroon, Chad, Congo - Republic, Congo - Democratic Republic, and São Tomé and } \\
\text { Principe; Eastern Africa: Ethiopia, Kenya, Madagascar, Rwanda, Tanzania, and Uganda; Southern Africa: Lesotho, } \\
\text { Malawi, Namibia, Mozambique, Swaziland (Eswatini), Zambia, and Zimbabwe; Western Africa: Benin, Burkina Faso, } \\
\text { Gambia, Ghana, Guinea, Ivory Coast, Liberia, Mali, Niger, Nigeria, Senegal, Sierra Leone, and Togo. }\end{array}$} \\
\hline \multicolumn{5}{|c|}{$\begin{array}{l}\text { Different geographical regions in Sub-Saharan Africa experience different HIV prevalence rates. In } \\
\text { ble } 9 \text {, we provide summary statistics of the HIV prevalence rate by region: Central, Eastern, Southern } \\
\text { d Western Africa. for our narrow sample A, Western African countries have the lowest average HIV } \\
\text { evalence rate at } 2 \text { percent, followed by Central African countries at } 2.8 \text { percent, Eastern African countries } \\
4 \text { percent, and Southern African countries at } 15.8 \text { percent. The same pattern holds for our full sample. } \\
\text { Table } 10 \text { A presents the marginal effect of the HIV prevalence on marriage by age cohorts of our narrow } \\
\text { mple among females in the regions of Sub-Saharan Africa. In each region, HIV prevalence increases } \\
\text { arriage for all age cohorts. For girls Age } 15-17 \text {, the greatest marriage response to HIV prevalence is found } \\
\text { Western Africa and the lowest response in Southern Africa, where the HIV prevalence rate is the lowest } \\
\text { d the highest, respectively. The estimates show that a one percentage rise in the HIV rate increases } \\
\text { arriage probability by } 3.07 \text { percentage points in Western Africa in contrast to } 0.62 \text { percentage points in } \\
\text { uthern Africa. The response is around } 1.8 \text { percentage points for both Central and Eastern Africa. For } \\
\text { horts ages } 18-30 \text {, compared to the other regions, Southern Africa also has the lowest marriage response } \\
\text { HIV prevalence, while Western Africa tends to show the highest response. }\end{array}$} \\
\hline
\end{tabular}


TABLE 10A

PROBIT MODEL MARGINAL EFFECT OF THE HIV PREVALENCE RATE ON MARRIAGE FOR FEMALES IN SAMPLE A WITHOUT EDUCATION AS AN EXPLANATORY VARIABLE

\begin{tabular}{|c|c|c|c|c|}
\hline & \multicolumn{4}{|c|}{ Female Sample A } \\
\hline & $\begin{array}{c}(1) \\
\text { Central Africa }\end{array}$ & $\begin{array}{c}(2) \\
\text { Eastern } \\
\text { Africa } \\
\end{array}$ & $\begin{array}{c}\text { (3) } \\
\text { Southern } \\
\text { Africa }\end{array}$ & $\begin{array}{c}\text { (4) } \\
\text { Western Africa }\end{array}$ \\
\hline Age 15 to 17 & $\begin{array}{c}0.0181 * * * \\
(0.0050)\end{array}$ & $\begin{array}{c}0.0179 * * * \\
(0.0039)\end{array}$ & $\begin{array}{c}0.0062 * * \\
(0.0011)\end{array}$ & $\begin{array}{c}0.0307 * * * \\
(0.0037)\end{array}$ \\
\hline Age 18 to 20 & $\begin{array}{c}0.0198 * * \\
(0.0079)\end{array}$ & $\begin{array}{c}0.0301 * * * \\
(0.0060)\end{array}$ & $\begin{array}{c}0.0115^{* * * *} \\
(0.0018)\end{array}$ & $\begin{array}{c}0.0334 * * * \\
(0.0050)\end{array}$ \\
\hline Age 21 to 25 & $\begin{array}{c}0.0224 * * * \\
(0.0097)\end{array}$ & $\begin{array}{c}0.0352 * * * \\
(0.0074)\end{array}$ & $\begin{array}{c}0.0128 * * * \\
(0.0020)\end{array}$ & $\begin{array}{c}0.0280 * * * \\
(0.0053)\end{array}$ \\
\hline Age 26 to 30 & $\begin{array}{c}0.0116 \\
(0.0091)\end{array}$ & $\begin{array}{c}0.0381 * * * \\
(0.0090)\end{array}$ & $\begin{array}{c}0.0131 * * * \\
(0.0024)\end{array}$ & $\begin{array}{c}0.0396 * * * \\
(0.0071)\end{array}$ \\
\hline Age 31 to 64 & $\begin{array}{c}0.0187 * * * \\
(0.0044)\end{array}$ & $\begin{array}{c}0.0142 * * * \\
(0.0023)\end{array}$ & $\begin{array}{c}0.0065^{* * *} \\
(0.0010)\end{array}$ & $\begin{array}{c}0.0372 * * * \\
(0.0043)\end{array}$ \\
\hline Observations & 24,646 & 37,647 & 44,133 & 66,676 \\
\hline Likelihood Ratio & 504.18 & 746.95 & 1717.90 & 1668.04 \\
\hline Pseudo R-Squared & 0.0471 & 0.0592 & 0.0816 & 0.0580 \\
\hline Fixed Effects & Country & Country & Country & Country \\
\hline
\end{tabular}

TABLE 10B

PROBIT MODEL MARGINAL EFFECT OF THE HIV PREVALENCE RATE ON MARRIAGE FOR FEMALES IN SAMPLE B WITHOUT EDUCATION AS AN EXPLANATORY VARIABLE

\begin{tabular}{lcccc}
\hline & \multicolumn{4}{c}{ Female Sample B } \\
\cline { 2 - 5 } & $(1)$ & $(2)$ & $(3)$ & $(4)$ \\
& Central & Eastern & $\begin{array}{c}\text { Southern } \\
\text { Africa }\end{array}$ & Western Africa \\
& Africa & Africa & & \\
Age 15 to 17 & $0.0638^{* * *}$ & $0.1527 * * *$ & $-0.0017^{* *}$ & $0.0471^{* * *}$ \\
& $(0.0038)$ & $(0.0013)$ & $(0.0008)$ & $(0.0031)$ \\
Age 18 to 20 & $0.0563^{* * *}$ & $0.1592^{* * *}$ & -0.0003 & $0.0363^{* * *}$ \\
& $(0.0040)$ & $(0.0013)$ & $(0.0009)$ & $(0.0036)$ \\
Age 21 to 25 & $0.0559^{* * *}$ & $0.1655^{* * *}$ & $-0.0018^{*}$ & $0.0341^{* * *}$ \\
& $(0.0043)$ & $(0.0013)$ & $(0.0009)$ & $(0.0039)$ \\
Age 26 to 30 & $0.0564 * * *$ & $0.1657^{* * *}$ & $-0.0055^{* * *}$ & $0.0366^{* * *}$ \\
& $(0.0058)$ & $(0.0018)$ & $(0.0012)$ & $(0.0050)$ \\
Age 31 to 64 & $0.0903 * * *$ & $0.1346 * * *$ & $-0.0064 * * *$ & $0.0641^{* * *}$ \\
& $(0.0022)$ & $(0.0012)$ & $(0.0004)$ & $(0.0015)$ \\
Observations & & & & \\
Likelihood Ratio & 67,552 & 88,849 & 109,375 & 193,986 \\
Pseudo R-Squared & 4176.85 & 18430.12 & 11373.34 & 11872.34 \\
Fixed Effects & 0.0480 & 0.1535 & 0.0784 & 0.0486 \\
\hline
\end{tabular}


In Table 10B, we provide the marginal effects using the whole sample B. Here, Eastern Africa has the highest marriage response to HIV prevalence: 13.46 to 16.57 percentage points increase in marriage probability corresponding to a one percentage point rise in the HIV rate, as opposed to the results from sample A showing Western Africa as the highest response region. Nevertheless, both sample A and B provide the same finding that Southern African is the region with the lowest response to the HIV prevalence. With sample B, furthermore, the percentage response in Southern Africa is negative for cohorts of ages 1530. For adolescent girls of Age 15-17, a one percentage point rise in the HIV prevalence results in a 0.17 percentage point decrease in their probability to marry. These results suggest that in a region suffering extremely from HIV prevalence, marriage may not be considered as a means of preventing HIV infection, because the likelihood of having a HIV infected person as a marriage partner is high. This is echoed by the findings of Clark, Poulin, and Kohler (2009) in Malawi, a country with an above average HIV prevalence rate, where girls do not seem to perceive marriage as a safety net from HIV contraction.

We further analyze the impact of the HIV rate on marriage for male cohorts by region. The estimated marginal effects in Table 11A, using sample A, shows a finding common in all regions that males' marriage response to a rising HIV rate is positive but smaller than females. Especially among boys Age 15-17, the response is negligible. As with the female sample, Southern Africa is again the region showing the smallest increase in marriage probability given a percentage point increase in the HIV prevalence rate. The results from sample B (Table 11B) show the same pattern: compared to the other regions, males in Southern Africa show the weakest marriage response to a HIV rate increase.

TABLE 11A

PROBIT MODEL MARGINAL EFFECT OF THE HIV PREVALENCE RATE ON MARRIAGE FOR MALES IN SAMPLE A WITHOUT EDUCATION AS AN EXPLANATORY VARIABLE

\begin{tabular}{lcccc}
\hline & \multicolumn{4}{c}{ Male Sample A } \\
\cline { 2 - 5 } & $\begin{array}{c}(1) \\
\text { Central }\end{array}$ & $\begin{array}{c}(2) \\
\text { Eastern }\end{array}$ & $\begin{array}{c}(3) \\
\text { Southern }\end{array}$ & \begin{tabular}{c} 
Western \\
\hline
\end{tabular} \\
Age 15 to 17 & $0.0016^{* * *}$ & 0.0001 & -0.0001 & $0.0008^{* *}$ \\
& $(0.0005)$ & $(0.0003)$ & $(0.0001)$ & $(0.0004)$ \\
Age 18 to 20 & $0.0065^{* * *}$ & $0.0035^{* *}$ & $0.0007 * *$ & $0.0063^{* * *}$ \\
& $(0.0019)$ & $(0.0012)$ & $(0.0003)$ & $(0.0010)$ \\
Age 21 to 25 & $0.0096^{* *}$ & $0.0062^{* * *}$ & $0.0021^{* * *}$ & $0.0125^{* * *}$ \\
& $(0.0033)$ & $(0.0021)$ & $(0.0007)$ & $(0.0021)$ \\
Age 26 to 30 & $0.0130^{* *}$ & $0.0077^{* * *}$ & $0.0029 * * *$ & $0.0157^{* * *}$ \\
& $(0.0043)$ & $(0.0029)$ & $(0.0010)$ & $(0.0029)$ \\
Age 31 to 64 & $0.0160^{* * *}$ & $0.0091 * * *$ & $0.0020^{* *}$ & $0.0204^{* * *}$ \\
& $(0.0040)$ & $(0.0025)$ & $(0.0008)$ & $(0.0031)$ \\
Observations & & & & \\
Likelihood Ratio & 17,154 & 25,609 & 33,253 & 50,845 \\
Pseudo R-Squared & 555.19 & 766.61 & 1426.79 & 1542.70 \\
Fixed Effects & 0.1208 & 0.1276 & 0.1536 & 0.1339 \\
\hline
\end{tabular}




\section{TABLE 11B}

PROBIT MODEL MARGINAL EFFECT OF THE HIV PREVALENCE RATE ON MARRIAGE FOR MALES IN SAMPLE B WITHOUT EDUCATION AS AN EXPLANATORY VARIABLE

\begin{tabular}{|c|c|c|c|c|}
\hline & \multicolumn{4}{|c|}{ Male Sample B } \\
\hline & $\begin{array}{c}(1) \\
\text { Central Africa }\end{array}$ & $\begin{array}{c}\text { (2) } \\
\text { Eastern Africa }\end{array}$ & $\begin{array}{c}(3) \\
\text { Southern } \\
\text { Africa }\end{array}$ & $\begin{array}{c}\text { (4) } \\
\text { Western } \\
\text { Africa }\end{array}$ \\
\hline Age 15 to 17 & $\begin{array}{c}0.0514 * * * \\
(0.0037)\end{array}$ & $\begin{array}{c}0.0338^{* * * *} \\
(0.0017)\end{array}$ & $\begin{array}{c}0.0049 * * * \\
(0.0007)\end{array}$ & $\begin{array}{c}0.0321 * * * \\
(0.0021)\end{array}$ \\
\hline Age 18 to 20 & $\begin{array}{c}0.0578 * * * \\
(0.0048)\end{array}$ & $\begin{array}{c}0.0762 * * * \\
(0.0021)\end{array}$ & $\begin{array}{c}0.0147 * * * \\
(0.0010)\end{array}$ & $\begin{array}{c}0.0570 * * * \\
(0.0031)\end{array}$ \\
\hline Age 21 to 25 & $\begin{array}{c}0.0626 * * * \\
(0.0046)\end{array}$ & $\begin{array}{c}0.0934 * * * \\
(0.0019)\end{array}$ & $\begin{array}{c}0.0137 * * * \\
(0.0009)\end{array}$ & $\begin{array}{c}0.0604 * * * \\
(0.0030)\end{array}$ \\
\hline Age 26 to 30 & $\begin{array}{c}0.0647 * * * \\
(0.0061)\end{array}$ & $\begin{array}{c}0.1060 * * * \\
(0.0026)\end{array}$ & $\begin{array}{c}0.0132 * * * \\
(0.0013)\end{array}$ & $\begin{array}{c}0.0512 * * * \\
(0.0039)\end{array}$ \\
\hline Age 31 to 64 & $\begin{array}{c}0.0769 * * * \\
(0.0031)\end{array}$ & $\begin{array}{c}0.0989 * * * \\
(0.0018)\end{array}$ & $\begin{array}{c}0.0083^{* * *} * \\
(0.0005)\end{array}$ & $\begin{array}{c}0.0627 * * * \\
(0.0021)\end{array}$ \\
\hline Observations & 35,097 & 48,432 & 61,822 & 100,367 \\
\hline Likelihood Ratio & 7102.33 & 16493.08 & 14670.27 & 22784.40 \\
\hline Pseudo R-Squared & 0.1463 & 0.2458 & 0.1714 & 0.1638 \\
\hline Fixed Effects & Country & Country & Country & Country \\
\hline
\end{tabular}

From the estimated probit model, which allows age cohorts as explanatory variables, the marriage effect of HIV prevalence is larger for the young people of ages 15-30 than the old. Also, the marriage effect for adolescent girls (Age 15-17), much larger than that for adolescent boys, is almost as high as that for females and males ages 18-30. We believe one of the reasons why the HIV epidemic increases marriage is that men as well as women seek to avoid contracting HIV by resorting to marriage instead of casual sex. As shown in Table 4, married women tend to be 6 to 10 years younger than their husbands. We assume this is partly because younger women tend to have lower HIV infection rates (Table 6). It is adolescent girls (Age 1517) that shows the largest husband-wife age difference. According to Table 5, women who married during adolescence (Age 15-17) fair the worst in educational attainment, 2.7 years of education, compared to all other marital status-gender-age groups (3.7-9.0 years of education). These observations seem to necessitate the efforts to discourage adolescent marriage among girls in Sub-Saharan Africa. ${ }^{6}$

\section{CONCLUSION}

To explore the relationship between the HIV epidemic and reduced human capital in Africa, we analyze the impact of the HIV epidemic on marriage in Sub-Saharan Africa. Our findings show that HIV prevalence increases the probability of marriage among Africans of all ages and sexes. Especially alarming is that the effect of HIV prevalence on marriage for adolescent girls is almost as high as the effect for mature age groups, whereas the effect for adolescent boys is negligible. A possible explanation for the considerably high marriage impact of HIV prevalence for adolescent girls is that younger girls are regarded as healthier marriage partners, since they are less exposed to sex and hence to HIV infection. These girls themselves may seek marriage as a means of HIV prevention. Ultimately, marriage for adolescent girls implies lower educational attainment for them. We also find that the impact of the HIV epidemic on marriage, which varies from region to region, is weakest in Southern Africa, the region with the highest degree of HIV prevalence. 


\section{ENDNOTES}

1. The consensus in the literature is that the HIV epidemic has little impact on fertility in Sub-Saharan Africa. However, there exists heterogeneous responses among different groups of people. Durevall and Lindskog (2011) show that the aggregate change in the fertility rate in Malawi due to the HIV epidemic is negligible, but the impact varies across age cohorts. For women ages 20-24 in districts where HIV prevalence is between 0 to 15 percent, they find a higher probability of having a first child. For women over 29 years old, they show that the HIV epidemic is associated with a decline in giving birth. Others have argued that the heterogeneity in fertility depends on the HIV status of the individual and their relative education attainment (Fortson, 2009; Juhn, Kalemli-Ozcan, \& Turan, 2013; Castro, Behrman, \& Kohler, 2015; Wilson, 2015).

2. We assume away multiple marriages for an individual for simplicity.

3. Gyimah (2009) notes that the endogeneity of education in the age at first marriage equation can be instrumented by parental characteristics. Field and Ambrus (2008) and Sekhri and Debnath (2014) use the age of menarche as an instrument for evaluating education outcomes of girls in Bangladesh and India, respectively. However, we lack these instruments in our dataset.

4. A few individuals reported marrying at age 14 or under. We do not consider them as part of sample B because $Y_{i}$ equals 1 for these individuals without exception so that an explanatory variable is identical to the dependent variable for them.

5. A precise model would consider each individual's entire history of yearly decisions and changing explanatory variables over years, not just those in the survey year. That approach would require bigger and better data sets, namely panel data.

6. Our suggestion is compatible with Duflo, Dupas, and Kremer (2015) that an effective policy in curtailing teenage school dropouts and sexual transmitted diseases is with educational programs focused on subsidizing schooling together with HIV education.

\section{REFERENCES}

Anglewicz, P., \& Reniers, G. (2014). HIV status, gender, and marriage dynamics among adults in rural Malawi. Studies in Family Planning, 45(4), 415-428.

Becker, G.S., \& Lewis, H.G. (1973). On the interaction between the quantity and quality of children. Journal of Political Economy, 81(2, Part 2), S279-S288.

Beegle, K., \& Krutikova, S. (2008). Adult mortality and children's transition into marriage. Demographic Research, 19(42), 1551-1574.

Castro, R., Behrman, J.R., \& Kohler, H.P. (2015). Perception of HIV risk and the quantity and quality of children: The case of rural Malawi. Journal of Population Economics, 28(1), 113-132.

Clark, S. (2004). Early marriage and HIV risks in sub-Saharan Africa. Studies in Family Planning, 35(3), 149-160.

Clark, S., Bruce, J., \& Dude, A. (2006). Protecting young women from HIV/AIDS: The case against child and adolescent marriage. International Family Planning Perspectives, 32(2), 79-88.

Clark, S., Poulin, M., \& Kohler, H.P. (2009). Marital aspirations, sexual behaviors, and HIV/AIDS in rural Malawi. Journal of Marriage and Family, 71(2), 396-416.

Duflo, E., Dupas, P., \& Kremer, M. (2015). Education, HIV, and early fertility: Experimental evidence from Kenya. American Economic Review, 105(9), 2757-97.

Durevall, D., \& Lindskog, A. (2011). Uncovering the impact of the HIV epidemic on fertility in SubSaharan Africa: The case of Malawi. Journal of Population Economics, 24(2), 629-655.

Field, E., \& Ambrus, A. (2008). Early marriage, age of menarche, and female schooling attainment in Bangladesh. Journal of Political Economy, 116(5), 881-930.

Fortson, J.G. (2009). HIV/AIDS and fertility. American Economic Journal: Applied Economics, 1(3), 170-94.

Fortson, J.G. (2011). Mortality risk and human capital investment: The Impact of HIV/AIDS in SubSaharan Africa. The Review of Economics and Statistics, 93(1), 1-15.

Grant, M.J., \& Soler-Hampejsek, E. (2014). HIV risk perceptions, the transition to marriage, and divorce in Southern Malawi. Studies in Family Planning, 45(3), 315-337. 
Greenwood, J., Kircher, P., Santos, C., \& Tertilt, M. (2017). The role of marriage in fighting HIV: A quantitative illustration for Malawi. American Economic Review, 107(5), 158-62.

Gyimah, S.O. (2009). Cohort differences in women's educational attainment and the transition to first marriage in Ghana. Population Research and Policy Review, 28(4), 455-471.

HRW. (2015). Ending Child Marriage in Africa: Opening the Door for Girls' Education, Health, and Freedom from Violence. New York: Human Rights Watch. Retrieved from https://www.hrw.org/sites/default/files/supporting_resources/ending_child_marriage_in_africaupdated_final.pdf

Juhn, C., Kalemli-Ozcan, S., \& Turan, B. (2013). HIV and fertility in Africa: First evidence from population-based surveys. Journal of Population Economics, 26(3), 835-853.

Palermo, T., \& Peterman, A. (2009). Are female orphans at risk for early marriage, early sexual debut, and teen pregnancy? Evidence from sub-Saharan Africa. Studies in Family Planning, 40(2), 101112.

Reniers, G. (2008). Marital strategies for regulating exposure to HIV. Demography, 45(2), 417-438.

Santhya, K.G., \& Jejeebhoy, S.J. (2007). Early marriage and HIV/AIDS: Risk factors among young women in India. Economic and Political Weekly, 42(14), 1291-1297.

SDG. (2017). The Sustainable Development Goals Report 2017. New York: United Nations Sustainable Development Goals. Retrieved from https://unstats.un.org/sdgs/files/report/2017/TheSustainableDevelopmentGoalsReport2017.pdf

Sekhri, S., \& Debnath, S. (2014). Intergenerational consequences of early age marriages of girls: Effect on children's human capital. The Journal of Development Studies, 50(12), 1670-1686.

Ueyama, M., \& Yamauchi, F. (2009). Marriage behavior response to prime-age adult mortality: Evidence from Malawi. Demography, 46(1), 43-63.

UNAIDS. (2011). UNAIDS World AIDS Day Report 2011. How to get to zero: Faster, smarter, better. Geneva: Joint United Nations Programme on HIV and AIDS. Retrieved from http://files.unaids.org/en/media/unaids/contentassets/documents/unaidspublication/2011/JC2216_ WorldAIDSday_report_2011_en.pdf

UNAIDS. (2014). Methodology - Understanding the HIV Estimates. Geneva: Joint United Nations Programme on HIV and AIDS. Retrieved from https://www.unaids.org/sites/default/files/media_ asset/UNAIDS_methodology_HIVestimates_en.pdf

UNAIDS. (2017). UNAIDS DATA 2017. Geneva: Joint United Nations Programme on HIV and AIDS. Retrieved from http://www.unaids.org/sites/default/files/media_asset/20170720_Data_book_2017_en.pdf

UNFPA. (2012). Marrying too Young: End Child Marriage. New York: United Nations Population Fund. Retrieved from https://www.unfpa.org/sites/default/files/pub-pdf/MarryingTooYoung.pdf

Wilson, N. (2015). Child mortality risk and fertility: Evidence from prevention of mother-to-child transmission of HIV. Journal of Development Economics, 116, 74-88. 